圽 36 巻 ${ }^{\text {震 }}$ (1983) $111-113$ 第 2 輯

\section{駿河トラフ西側域の 地震活動}

\author{
静岡地方気象台 \\ 吉田 明 夫
}

(昭和 57 年 10 月 1 日受理)

Seismicity on the West Side of Suruga Trough

Akio YosHIDA

Shizuoka Local Meteorological Observatory

(Received October 1, 1982)

特徵的なパターン Fig. $1 \mathrm{a}$, Fig. $1 \mathrm{~b}$, Fig. $1 \mathrm{c}$ は 1961 年から 1982 年 6 月までの駿河トラフ西 側域の地震活動を深さ別に描いたものである. 資料 は気象庁地震月報により，Fig. $1 \mathrm{a}$ は深さ $0 \sim 20$ km, Fig. $1 \mathrm{~b}$ は深さ $30 \mathrm{~km}$, Fig. $1 \mathrm{c}$ 深さ $40 \sim$ $60 \mathrm{~km}$ の地震の震央で $M 2.5$ 以上の地震をすべて プロットしてある. これらのうら Fig. 1c とは, 駿河湾西岸中央部加静岡, 愛知, 長野県境に向か つて，すなわらほぼ南東一北西方向に顕著な震央分 布の線状配列が認められる. 深さ $30 \mathrm{~km}$ の地震活 動もこの線状配列付近で活発であり，かつそれから 両側にしみだす傾向もみせている. しかし深さ 0 $20 \mathrm{~km}$ の地震活動には, 1965 年の $M 6.1$ の地震 の震央付近に集中した活動がみられるほかはこのよ らな配列のパターンはなく，むしろ駿河湾西岸域全 体に分散しているようにみ兄る。

Fig. 2 はこれらの地震をすべて一枚の図にまと め，かつ $1000 \mathrm{~m}$ の等高線を描き入れたものであ る. Fig. $1 \mathrm{a}$ の震央分布には一見してはつきりした 特徴はみられなかつたが，Fig. 2 をみると，これ らの地震は, 深さ $30 \sim 60 \mathrm{~km}$ の地震も含めて, 注 ぼちょうど $1000 \mathrm{~m}$ 以上の山塊をとりまいて分布し ていることがみてとれる，そして先に述べた線状配 列はこの山塊の南限を区切つている.

Fig. $3 \mathrm{a}$, Fig. $3 \mathrm{~b}$ は 1974 年伊豆半島沖地震を
境にしてその前後の地震活動を分け, $M 3.0$ 以上の 地震をプロットしたものである. $M 3.0$ で切つたの は, 1974 年以前に拈いては $M 3.0$ 以下の地震のマ グニチュードがほとんど求められていないことによ る. Fig. 3 a には先の線状配列付近に活発な地震活 動がみられるが，Fig. 3b はむしろ全体に散らばる 傾向をみせているこれをよりはつきりとみるため に, Fig. 4 に示した $2 つ の$ 領域 A, B について, それぞれ 2 次元的な時空間分布を調べた。

Fig. $5 \mathrm{a}$ は北 $50^{\circ}$ 西飞細長い領域 A (幅 $20 \mathrm{~km}$, 長さ $100 \mathrm{~km})$ をとり，この幅方向の位置は問題と せずに，駿河湾西岸の境界からどれだけ離れたと ころで発生したかに着目してその距離を縱軸に，横 軸に年をとつてプロットしたものである．線状配列 付近の地震活動にその方向での震源の移動がみられ るかどうかを調べたものだが，Fig. $5 \mathrm{a}$ を見る限 り，かすかに南東部から北西部へ，あるいはその逆 に移動する傾向があるようにもみ兄るものの，いず れにしてもはつきりしたるのはない。

一方，Fig. $5 \mathrm{~b}$ は駿河湾西岸に沿つて北 $40^{\circ}$ 東 方向飞領域 B（幅 $50 \mathrm{~km}$, 長さ $100 \mathrm{~km}$ ) をとり,や はり幅方向の位置は区別せずに，南西端からの距離 を縦軸に，年を横軸にとつてプロットしたものだ が，この図からは 1974 年を境にして明らかにパタ ーンの変化が認めら杴る。すなわち 1974 年以前は いわゆる線状配列付近に活動が集中していたのに対 して，以後は引続きそこで活発な活動がみられるも のの周囲にも広く分散している. ただし，駿河湾北 部沿岸地域は逆に空白となつている。これらの変化 は極めて顕著である。

構造線 駿河湾西岸中央部の焼津付近から静岡, 愛知，長野県境に向かつてやや深くテクトニックな 構造線が存在している可能性がある。これは茂木 (1977) のいら活構造線と方向が一致しているが, しかし石廊崎断層の延長としてあるというょりも， むしろ静岡県中央部をほぼ南東一北西に切る構造が まずあつて，その延長線上に石廊崎断層がきている とみるべきと思われる.この構造線が赤石山塊の南 限を区切つているのは，その存在が南アルプスの隆 起と密接に関係していることを示唆している。そし て浅い地震活動にそれ汪ど明らかでなく，やや深い 地震活動に顕著にみられるのは，この構造線が上盤 

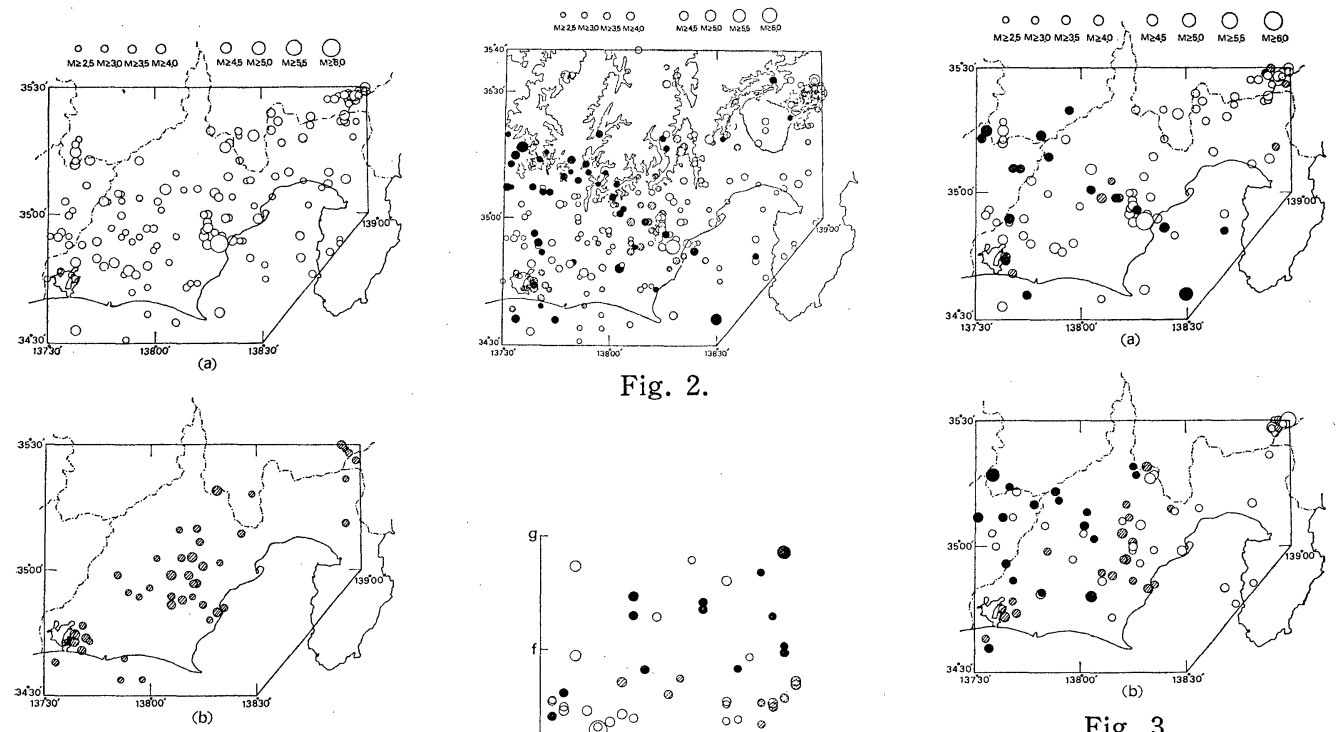

Fig. 2.

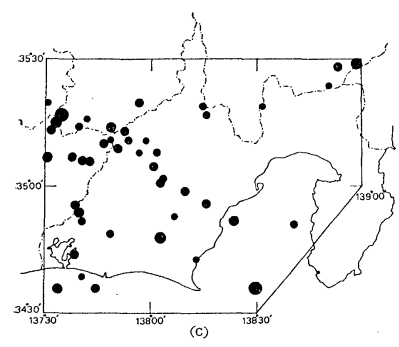

Fig. 1.
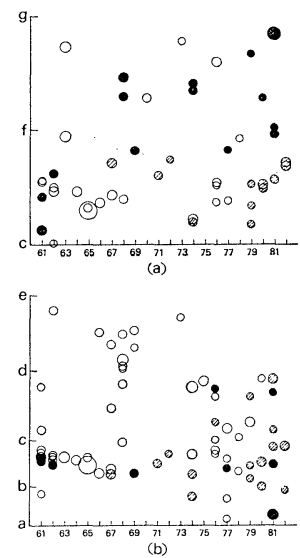

Fig. 5.

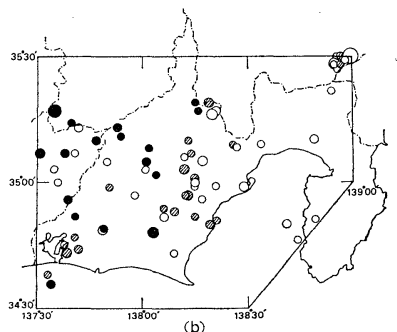

Fig. 3 .

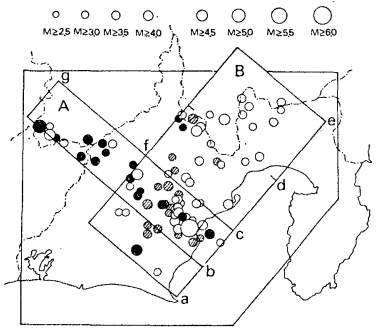

Fig. 4.

Fig. 1. Seismicity on the west side of Suruga Trough during the period from 1961 through June 1982; the magnitude is larger than 2.5, and the depth of hypocenter is (a) 0-20 $\mathrm{km}$, (b) $30 \mathrm{~km}$, (c) $40-60 \mathrm{~km}$, respectively. In figure (c) a patern of linear distribution to the North West direction is clearly recognized in the central region of Shizuoka prefecture, and the seismic activity in figure (b) is also high around this region, but in figure (a) such a feature is not seen.

Fig. 2. Earthquakes of $M \geq 2.5$ shallower than $60 \mathrm{~km}$ are all plotted and a $1000 \mathrm{~m}$ contour line is also drawn. It is seen that earthquakes are distributed surrounding the contour line, and the former linear arrangement is situated on the south of it marking off the mountain mass.

Fig. 3. (a) Seismicity larger than $M 3.0$ during the period from 1961 through May 9, 1974 when Izu-Hanto-Oki earthquake occurred. Concentrated activity is seen around the region of linear arrangement. (b) Seismicity larger than $M 3.0$ after Izu-Hanto-Oki earthquake to June 1982. Epicenters near the linear arrangement are extended over a wider area than the former period.

Fig. 4. Seismicity larger than $M 3.0$ during the period from 1961 through June 1982 in the region $A$ (width $10 \mathrm{~km}$, length $100 \mathrm{~km}$, the direction of extention is $\mathrm{N} 50^{\circ} \mathrm{W}$ ) and $\mathrm{B}$ (width $50 \mathrm{~km}$, length $100 \mathrm{~km}$, the direction of extention is $\mathrm{N} 40^{\circ} \mathrm{E}$ ).

Fig. 5. (a) Two dimensional space-time distribution in the region A. A trend of epicenter migration along the linear arrangement is slightly observed but it is not conspicuous. (b) Two dimensional space-time distribution in the region $\mathrm{B}$. A change of pattern is clearly recognized in 1974. Before then activity is concentrated around the linear arrangement, but later earthquakes are extended over a broader zone. 
の地殼内にではなく，もぐり込むフィリピン海プ レートに関係したものであることを示しているよう に思われる。恒石・杉山 (1978) は, 駿河湾西岸の, 石廊崎断層を延長した部分に駿豆断層が存在すると しているが，活断層研究会編（1980）の「日本の活 断層」にはこの付近に活断層が記載されていない。 いずれにしても地震の線状配列に沿つて大規模な断 層が地表で観察されないのは，この構造が比較的深 いるのであるとすれば理解できる。

この構造線沿い，静岡付近では今世紀に入つて 1917 年に $M 6.3,1935$ 年に $M 6.3,1965$ 年に $M 6.1$ の地震が発生している。 また 1854 年安政東 海地震の時にもこの付近で顕著な余震活動があつた [都司 (1982)] 注か，1944 年東南海地震の際にも誘 発された活発な地震活動があつた形跡がある。また 最近の微小地震活動からみても, 静岡付近は定常的 に活発な地域であることが知られている [山崎・大 井田 (1979)]. 特に Fig. 5 b にみられるように, 1974 年伊豆半島沖地震の前にはこの構造線付近に 集中した地震活動があつた。これに対して石廊崎断 層付近では 1974 年伊豆半島沖地震を別にして, 近 年の定常地震活動はそれほど活発とはい光ない。こ のような地震活動の特徵も, 構造線の主要な部分が 駿河トラフからもぐり込んだプレートの内にあるこ とを示しているとみてよいだろう。

このテクトニックな構造線と赤石山脈の隆起との 間に推定される密接な関係を考慮して，ここでは以 下さしあたつて，これを赤石一石廊崎線と呼ぶこと にする.

議論 駿河トラフ北半分は南半分とテクトニック な性格が異なるという見方は，すでにこの付近のプ レート境界を最初に提唱した杉村 (1972) によつて だされている．最近の微小地震活動からも，青木 （1980）は，駿河湾中央部を境に，その北東側では $25 \mathrm{~km}$ より深い地震が注とんどない等の違いにふれ たうえで，駿河湾北部の地殼深部はフィリピン海プ レートで単に押しているだけ，そこでのプレートの 運動は石廊崎-静岡線以西と全く様相が 異なるとす る見方が可能であろうと述べている，赤石一石廊崎 線は, 伊豆半島の衝突の結果生じた, 茂木 (1977) の いうようなフィリピン海プレート内のさけ目 [fingering] であつて，それは先端付近にまで達し，周
辺の地震活動や赤石山脈の隆起に深く関わつている テクトニックな主要構造線である可能性がある.す でに多くの人によつて指摘されているように, 赤石一 石廊崎線の北側では，フィリピン海プレートはもぐ り込反つつも押す要素が大きいのではなからうか。

駿河トラフ西側で発生する地震の発震機構が, 最 大主圧力軸の方向として南北を与える [ICHIKAWA (1971)；鵜川 (1981)] のは, 必ずしもこの付近に 南北方向の压縮力が作用しているためと考㝋なくて も,赤石一石廊崎線に沿らずれ運動に伴なつて発生す る地震が, 結果として南北主圧力軸の発震機構を示 すといら解釈も可能かもしれない.な拉 fingeringが もぐり込み付近で上盤側にも影響を与えていること は十分に考えられる。

赤石一石廊崎線の存在と意義を更にはつきりさせ るためには, 地震活動の詳細な検討に加えて, 重力, 地殼変動, 地質構造等の面からも総合的に調べる必 要があうう。

草稿を読んで有益な助言を下さつた静岡大学檀原 毅教授, 里村幹夫助教授と, 資料の整理を手伝つて いただいた気象庁地震予知情報課岸尾政弘氏に招礼 申しあげます。

\section{文献}

青木治三, 1980, 駿河湾西方に打汀る深発地震帯, 地震予知シンポジウム， 97-102.

ICHIKAWA, M., 1971, Reanalyses of Mechanism of Earthquakes which Occurred in and near Japan, and Statistical Studies on the Nodal Plane Solutions Obtained, 1926-1968, Geophys. Mag., 35, 207-274.

活断層研究会編, 1980, 日本の活断層, 東京大学出 版会, pp. 363.

茂木清夫, 1977 , 伊豆・東海地域の最近の地殼活動 の一解棌, 地震研究所彙報, 52, 315-331.

杉村 新, 1972, 日本付近に打けるプレートの境 界, 科学, 42, 192-202.

都司嘉宣, 1982, 私信.

恒石幸正・杉山雄一，1978，駿河トラフを横断する 駿豆断層, 地震予知連絡会会報, 20. 138-141.

鵜川元雄, 1981 , 中部地方・西南日本の地殼底地震 発生のメカニズム, 地震学会講演予稿集, No. 1, p. 56.

山崎文人 ・ 大井田 徹, 1979 , 駿河湾及びその周辺 の地震活動, 地震 2, 32, 451-462. 